show that H.A.A. persistence in these patients is probably not the result of gross deficiency in the host immune response.

The authors acknowledge the technical help of Miss Praful Damani and the help of Steven Lwanga with statistics. Dr. John Ziegler provided valuable help in the preparation of the text.

This work is supported by contract No. PH43-67-1343 from the

National Cancer Institutes, Bethesda, Maryland, U.S.A.

Requests for reprints should be addressed to: Dr. Aron Primack, N.C.I.-V.A. Oncology Unit, V.A. Hospital, 50 Irving Street N.W., Washington, D.C., 20422, U.S.A.

\section{References}

Alpert, E., and Isselbacher, K. J. (1971). Lancet, 2, 1087.

Anand, S, and Malaviya, A. N. (1971). Lancet, 2, 1032

Agarwaal, S. S., et al. (1970). Fournal of Clinical Investigation, 49, 161

Bagshawe, A. F., Parker, A. M., and Jindani, A. (1971). British Medical fournal, 1,88

Blumberg, B. S., Friedlaender, J. S., Woodside, A., and Sutnick, A. I. (1969). Proceedings of the National Academy of Sciences of the U.S.A., 62, 1108. Bluming, A. Z., Vogel, C. L., Ziegler, J. L., Mody, N., and Kamya, G. (1972). Annals of Internal Medicine, 76, 405.

Brown, R. B., et al. (1967). Annals of Internal Medicine, 1967, 67, 291.

Denison, E. K., Peters, R. L., and Reynolds, T. B. (1971). Annals of Internal Medicine, 74, 391 .

Fahey, J. L., and McKelvey, E. M. (1965). fournal of Immunology, 94, 84.
Gocke, D. J., and Howe, C. (1970). Fournal of Immunology, 104, 1031. Grabar, A. (1958). Advances in Protein Chemistry, 13, 1.

Hadziyannis, S. J., Merikas, G. E., and Afroudakis, A. P. (1970). Lancet, 2, 100.

Miller, D. G. (1962). Annals of Internal Medicine, 57, 703.

Okochi, K., and Murakami, S. (1968). Vox Sanguinis, 15, 374.

Peterson, M. R., Barker, L. F., and Schade, D. Vox Sanguinis. In press.

Prince, A. M., LeBlanc, L., Krohn, K. Masseyeff, R., and Alpert, M. E. (1970). Lancet, 2, 717.

Sherlock, S., Niazi, S. P., Fox, R. A., and Scheuer, P. J. (1970). Lancet, 1,1243 .

Shulman, N. R., and Barker, L. F. (1969). Science, 165, 300

Smith, J. B., and Blumberg, B. S. (1969). Lancet, 2, 953.

Sutnick, A. I., London, W. T., and Blumberg, B. S. (1969). Archives of Internal Medicine, 124, 722 .

Sutnick, A. I., et al. (1970). Fournal of the National Cancer Institute, 44, 1241.

Terés, J., Guardia, J., Bruguera, M., and Rodes, J. (1971). Lancet, 2, 215.

Tong, M. J., et al. (1971). Annals of Internal Medicine, 75, 687

Vogel, C. L., Anthony, P. P., Mody, N., and Barker, L. F. (1970). Lancet, 2 , 621 .

Vogel, C. L., Anthony, P. P., Sadikali, F., Barker, L. F., and Peterson, M. R. (1972). Fournal of the National Cancer Institute, $47,1583$.

Vogel, C. L., and Linsell, C. A. (1972). Fournal of the National Cancer Institute, 48, 567.

Vyas, G. N., and Shulman, N. R. (1970). Science, 170, 33.

Waldorf, D. S., Sheagren, J. N., Trautman, J. R., and Block, J. B. (1966). Lancet, 2, 773 .

Welsh, J. D., et al. (1972). Lancet, 1, 592.

Wilson, W. E. C., Kirkpatrick, C. H., and Talmage, D. W. (1965). Annals of Internal Medicine, 62,

Wright, G. G., and Feinberg, R. J. (1952). Fournal of Immunology, 68, 65.

Wright, R., McCollum, R. W., and Klatskin, G. (1969). Lancet, 2, 117.

Ziegler, J. L., Lewis, M. G., Luyombya, J. M. S., and Kiryabwire, J. W. M. (1969). British fournal of Cancer, 23, 729.

\title{
Coagulation Changes during Termination of Pregnancy by Prostaglandins and by Vacuum Aspiration
}

Nuffield Department of Obstetrics and Gynaecology, John Radclifie Hospital, Oxford OX3 9DU

M. H. H. BADRAOUI, M.B., M.S., Clinical demonstrator (Present address: Department of Obstetrics and Gynaecology, Faculty of Medicine, Ai Azhar University, Cairo, Egypt)

JOHN BONNAR, M.D., F.R.C.O.G., First Assistant

KEITH HILLIER, B.SC., PH.D., Research Officer

M. P. EMBREY, M.D., F.R.C.o.G., First Assistant known about changes in blood coagulation during termination of pregnancy.

After intra-amniotic injection of hypertonic saline to induce mid-trimester abortion, changes in coagulation factors have been reported which are consistent with disseminated intravascular coagulation (Stander et al., 1971). In view of this we investigated the coagulation system during induction of midtrimester abortion with prostaglandin $\mathrm{F}_{2} \alpha$ and the termination of pregnancy in the first trimester by vacuum aspiration.

\section{Patients and Methods}

Twelve patients were studied aged 18 to 37 years (mean 23 years) and parity one to seven, having termination of pregnancy at 14 to 20 weeks' gestation (mean 17 weeks) by extra-amniotic prostaglandin $\mathrm{F}_{2} \alpha$. Eleven patients were studied aged 18 to 39 years (mean 24 years) and parity one to four, having termination of their pregnancies by vacuum aspiration at eight to 12 weeks' gestation (mean 10 weeks).

Termination by Extra-amniotic Prostaglandin $F_{2} \alpha_{0}-\mathrm{A}$ Foley catheter was inserted through the cervix into the extra-amniotic space and the bulb was inflated with $40 \mathrm{ml}$ of distilled water. A test dose of $250 \mu \mathrm{g}$ of prostaglandin $\mathrm{F}_{2} \alpha$ was injected into the extra-amniotic space via the Foley catheter. If no side effects occurred $750 \mu \mathrm{g}$ was instilled at two-hourly intervals until abortion took place. Samples of venous blood $(18 \mathrm{ml})$ were withdrawn into a plastic syringe at the following stages: 1 , before administration of prostaglandin $\mathrm{F}_{2} \alpha ; 2$, when uterine contractions were established two to four hours after the first instillation of prostaglandin, 3; immediately after the expulsion of the products of conception; and 4, twenty-four hours after abortion.

Termination by Vacuum Aspiration.-This operation was carried out under general anaesthesia by using a Karman suction curette. Venous blood samples $(18 \mathrm{ml})$ were withdrawn 
at the following stages: 1 , before operation; 2 , immediately after completion of vacuum aspiration; and 3, twenty-four hours after operation.

\section{COAGULATION TESTS}

A 9-ml sample of blood was added to $1 \mathrm{ml}$ of $3.8 \%$ sodium citrate for coagulation assays, $5 \mathrm{ml}$ to $0.05 \mathrm{ml}$ of aprotinin $(5,000$ units $/ \mathrm{ml})$ for assay of fibrin degradation products, and $4 \mathrm{ml}$ to edetic acid for platelet counting.

Prothrombin time was measured by the method of Quick (1966) and partial thromboplastin time by using Bell and Alton's (1954) platelet substitute. Fibrin degradation products were assayed by the tanned red cell haemagglutination method (Merskey et al., 1966; Bonnar et al., 1969). Platelets were counted on a Coulter counter. Factors V and VII and X were assayed by the method of Stefanini and Dameshek (1962). Factor VIII was assayed by the two-stage method of Biggs et al. (1955). Factor X was assayed as described by Denson (1961).

\section{STATISTICAL ANALYSIS}

The factors were subjected to Wilcoxon's signed ranks test to determine the statistical significance of changes in the clotting factors.

\section{Results}

In the prostaglandin group a significant decrease in prothrombin time occurred during uterine contractions and at the time of abortion (table I). No significant changes were found with vacuum termination (Wilcoxon's signed ranks test).

In both the prostaglandin and vacuum aspiration groups no significant changes in partial thromboplastin time, platelet count, and levels of fibrin degradation products occurred.

During prostaglandin termination the levels of coagulation factors rose in most of the patients, and the increase of factors $\mathrm{V}, \mathrm{VIII}$, and $\mathrm{X}$ were significant during uterine contractions and at the time of abortion. Virtually no changes occurred with vacuum termination (table II). As shown in the chart the initial levels of coagulation factors X and VII and X in patients baving prostaglandin termination were significantly higher

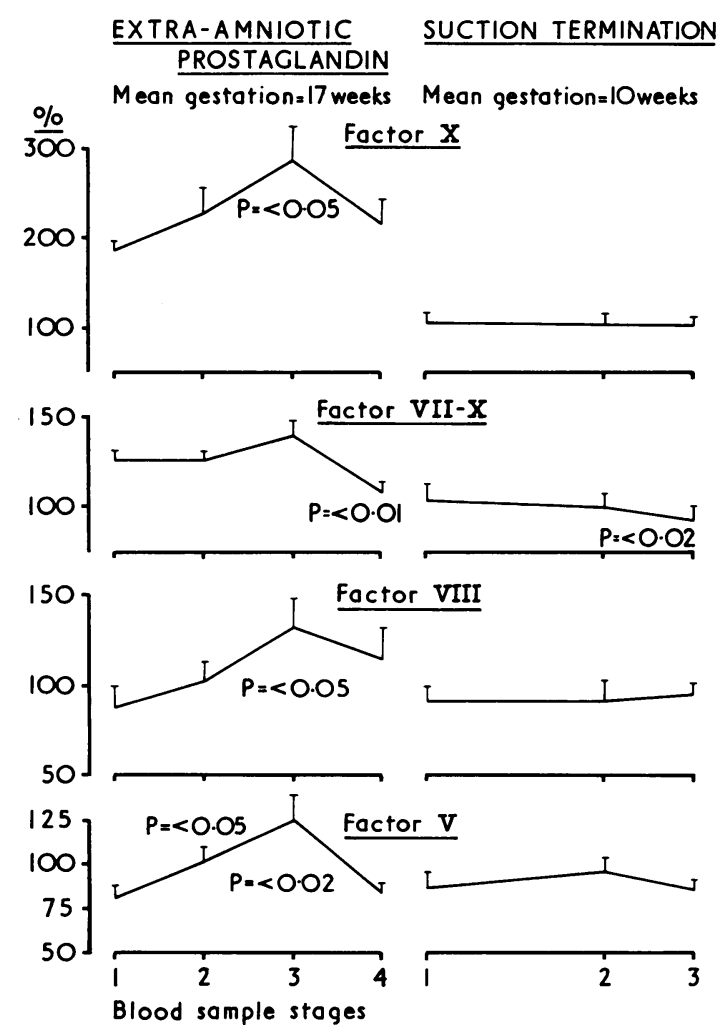
Coagulation factor changes during termination of pregnancy by vacuum
aspiration in first trimester and by extra-amniotic prostaglandin $F_{\alpha} \alpha$ in aspiration in first trimester and by extra-amniotic prostaglandin $F_{y} \alpha$ in cal significance of changes in clotting factors. For sample stages, see text.

than the preoperative levels in patients undergoing vacuum termination. Twenty-four hours after abortion the levels of coagulation factors in the prostaglandin group had returned to the preinduction values.

\section{Discussion}

Normal pregnancy is accompanied by major changes in the haemostatic mechanism, particularly an increase in the levels of certain coagulation factors and a noticeable decrease in fibrino-

TABLE I-Coagulation System Changes during Mid-trimester Abortion with Extra-amniotic Prostaglandin $F_{2} \alpha$

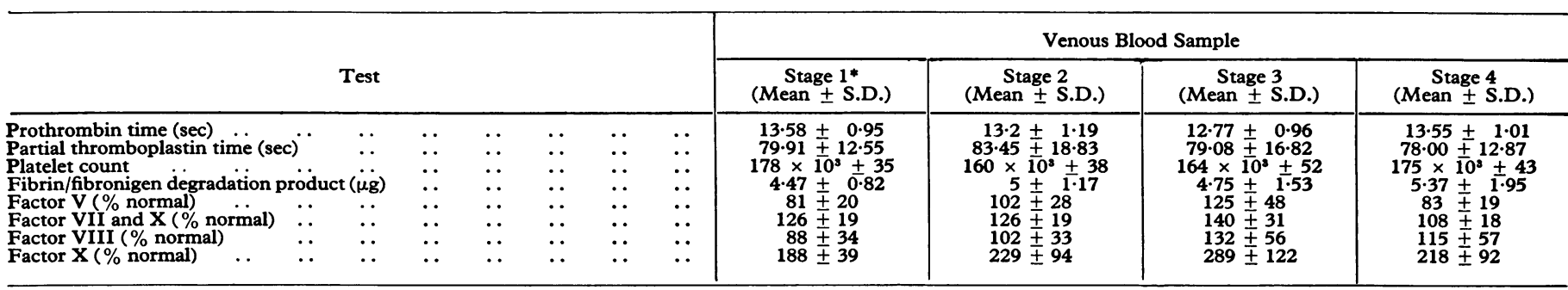

* For explanation of sample stages, see text.

TABLE II-Coagulation System Changes during First-trimester Abortion by Vacuum Aspiration

\begin{tabular}{|c|c|c|c|c|c|c|c|c|c|}
\hline & & & & & & & \multicolumn{3}{|c|}{ Venous Blood Sample } \\
\hline \multicolumn{7}{|c|}{ Test } & $\begin{array}{c}\text { Stage } 1^{*} \\
\text { (Mean } \pm \text { S.D.) }\end{array}$ & $\begin{array}{c}\text { Stage } 2 \\
\text { (Mean } \pm \text { S.D. })\end{array}$ & $\begin{array}{c}\text { Stage } 3 \\
\text { (Mean } \pm \text { S.D.) }\end{array}$ \\
\hline 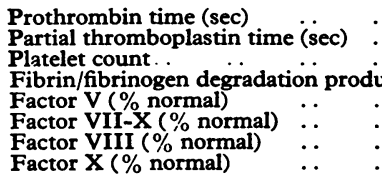 & 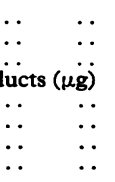 & $\begin{array}{l}\because \\
\because \\
\because \\
\because \\
\because \\
\cdots\end{array}$ & $\begin{array}{l}\because \\
\because \\
\because \\
\because \\
\because \\
\because\end{array}$ & $\begin{array}{l}\because \\
\because \\
\because \\
\because \\
\therefore\end{array}$ & $\begin{array}{l}\because \\
\because \\
\because \\
\because \\
\therefore\end{array}$ & $\begin{array}{l}. \\
\because \\
\because \\
\because \\
\because \\
\because\end{array}$ & $\begin{array}{c}13.5 \pm 1.04 \\
70 \cdot 77 \pm 8.39 \\
180 \times 10^{3} \pm 24 \\
3.52 \pm 1.66 \\
88 \pm 26 \\
104 \pm 30 \\
92 \pm 28 \\
103 \pm 34\end{array}$ & $\begin{array}{c}13 \cdot 72 \pm 0.93 \\
74 \cdot 27 \pm 12 \cdot 71 \\
154 \times 10^{3} \pm 30 \\
3 \cdot 86 \pm 1 \cdot 71 \\
95 \pm 25 \\
100 \pm 24 \\
92 \pm 37 \\
105 \pm 27\end{array}$ & $\begin{array}{c}14 \cdot 13 \pm 1 \cdot 26 \\
70 \cdot 68 \pm 8 \cdot 62 \\
155 \times 10^{3} \pm 29 \\
4 \cdot 2 \pm 1 \cdot 28 \\
86 \pm 15 \\
93 \pm 23 \\
95 \pm 18 \\
102 \pm 31\end{array}$ \\
\hline
\end{tabular}

*For explanation of sample stages, see text. 
lytic activity. Such changes have been interpreted as a physiological development to provide for effective haemostasis and preservation of the maternal blood volume during parturition (Bonnar et al., 1971). The increased levels of coagulation factors associated with pregnancy have been reported as occurring, in the main, in the third trimester.

In the present study factors VII and X were found to be increased early in the second trimester. An increase of similar magnitude in the activity of these factors at an unspecified time during the second trimester was reported by Nilsson and Kullander (1967). Already there are reports emphasizing the haemhorragic complications of therapeutic abortion, and it is likely that in some instances defective blood coagulation may be responsible.

The increase in the activity of factors V, VIII, and X which were found during induction of abortion in mid-trimester pregnancy by extra-amniotic prostaglandin $\mathrm{F}_{2} \alpha$ indicates that activation of the coagulation system is taking place. In particular the increase of factor X may be due to the escape of thromboplastin substances from the placental site during uterine contractions and especially at the time of placental separation. It has been shown in hamsters that thromboplastin material enters both the maternal and fetal circulation during placenta separation (Brown and Stalker, 1969). During placental separation at term in normal pregnancies increased levels of coagulation factors V and VIII have been found in both peripheral and uterine blood (Bonnar et al., 1970). Stander et al. (1971) suggested that induction of abortion by intra-amniotic injection of hypertonic saline initiates disseminated intravascular coagulation. They reported more extensive changes than were found in the present study.

It is of interest that virtually no changes in the coagulation system were found during termination of early pregnancy by vacuum aspiration. It seems, therefore, that when pregnancy is terminated in the mid-trimester, whether by hypertonic saline instillation or by extra-amniotic prostaglandin, coagulation system changes in the circulating blood take place. These are most probably related to the physiological changes which have taken place in the haemostatic system in the second trimester. Coagulation changes associated with abortion will establish a vulnerable state for intravascular clotting and thromboembolic complications. It is likely, therefore, that in susceptible patients termination of pregnancy after the first trimester may give rise to such complications as defective haemostasis or thromboembolic complications.

We wish to thank the consultant staff of the division of obstetrics and gynaecology for allowing us to study patients under their care. We gratefully acknowledge gifts of prostaglandin $F_{2} \alpha$ from Dr. R. Jacomb, of the Upjohn Company.

One of us (M.H.H.B.) was on study leave from the department of obstetrics and gynaecology, Al Azhar University, Cairo, and was in receipt of a Ford Foundation Fellowship. This investigation has been supported in part by the Agency for International Development contract No. AID/Csd 2837 (granted to K.H. and M.P.E.).

We thank Mr. M. Haddon and Mrs. J. Fairweather for expert technical help.

Requests for reprints should be sent to Dr. M. H. H. Badraoui, Al Azhar University, Cairo, Egypt.

\section{References}

Bell, W. N., and Alton, H. G. (1954). Nature, 174, 880.

Biggs, R., Eveling, J., and Richards, G. (1955). British fournal of Haematology, $1,20$.

Bonnar, J., Davidson, J. F., Podgeon, C. F., McNicol, G. P., and Douglas, A. S. (1969). British Medical fournal, 3, 137.

Bonnar, J., McNicol, G. P., and Douglas, A. S. (1971). In Scientific Basis of Obstetrics and Gynaecology, ed. R. R. Macdonald, London, Churchill.

Bonnar, J., Prentice, C. R. M., McNicol, G. P., and Douglas, A. S. (1970). British Medical fournal, 2, 564.

Brown, L. J., and Stalker, A. L. (1969). Microvascular Research, 1, 403.

Denson, K. W. (1961). Acta Haematologica, 25, 105.

Merskey, C., Kleiner, G. J., and Johnson, A. J. (1966). Blood, 28, 1.

Nilsson, I. M., and Kullander, S. (1967). Acta Obstetricia et Gynecologica Scandinavica, 46, 273.

Quick, A. J. (1966). Haemorrhagic Disease and Thrombosis, p. 391. Philadelphia, Lea and Febiger.

Stander, R. W., Flessa, H. C., Glueck, H. I., and Kisker, C. T. (1971). Obstetrics and Gynaecology, 37, 660 .

Stefanini, M., and Dameshek, W. (1962). Haemorrhagic Disorders, p. 451. New York, Grune and Stratton.

\section{Problem of the Old and the Cold*}

\section{R. H. FOX, R. MacGIBBON, LOUISE DAVIES, PATRICIA M. WOODWARD}

British Medical fournal, 1973, 1, 21-24

\section{Summary}

A pilot winter study of body temperatures using new measuring techniques was tested on 72 volunteers aged 65 or more living in Portsmouth. The body temperatures were related to their environmental temperature and living conditions. No case of serious hypothermia was found, but the study confirms that elderly people have

* This work was one of two pilot studies preceding a major study on 2,000 elderly people in 1972. It is hoped to publish the results of the main study, which was a collaboration between the Centre for Environmental Studies (Professor D. Donnison and Mr. M. Wicks), the Medical Research Council (Dr. R. H. Fox and Miss P. M. Woodward), University College Hospital
(Dr. A. N. Exton-Smith), and the Royal Free Hospital (Dr. M. F. Green), early in 1973 .

Division of Human Physiology, National Institute for Med:cal Research, London NW3 6RB

R. H. FOX, M.B., M.R.C.S., Member of Scientific Staff

R. MACGIBBON, M.B., B.S., Associate Research Worker

PATRICIA M. WOODWARD, B.Sc., Member of Scientific Staff

Queen Elizabeth College, London W8

LOUISE DAVIES, B.SC., Head of Geriatric Nutrition Unit lower body temperatures and suggests that the coldest individuals tended to be the least aware of discomfort from the cold; this may well place them "at risk" for developing hypothermia.

\section{Introduction}

The incidence of hypothermia of the elderly is uncertain, with estimates varying from the hundred or so returns on the Registrar General's death certificates to over 20,000 deaths annually (Taylor, 1964). A committee of the Royal College of Physicians (1966) estimated that in a three-month winter period in Britain there could be 9,000 hospital admissions with hypothermia (rectal temperature $<35^{\circ} \mathrm{C}$ ).

Mouth temperature was advocated for the diagnosis of hypothermia (a deep body temperature below $35^{\circ} \mathrm{C}\left(95^{\circ} \mathrm{F}\right)$ ) by a special committee for the British Medical Association (1964). In the winter survey undertaken by the Society of Medical Officers of Health (1968), $11.4 \%$ of all mouth temperatures of elderly people living at home were $35^{\circ} \mathrm{C}$ or below. In another similar survey (Williams, 1968), $5 \cdot 1 \%$ of mouth temperatures were below $35^{\circ} \mathrm{C}$ and $17.8 \%$ were below $35.5^{\circ} \mathrm{C}\left(95.9^{\circ} \mathrm{F}\right)$. Many of the 